\title{
PLASMID PROFILE IN ORAL Fusobacterium nucleatum FROM HUMANS AND Cebus apella MONKEYS
}

\author{
Marcia O. PAUla(1), Elerson GAETTI-JARDiM Jr.(2) \& Mario J. AVILA-CAMPOS(3)
}

\begin{abstract}
SUMMARY
Fusobacterium nucleatum is a strict anaerobe and is indigenous of the human oral cavity. This organism is commonly recovered from different monomicrobial and mixed infections in humans and animals. In this study, the plasmid profile, the plasmid stability and the penicillin-resistance association in oral $F$. nucleatum isolated from periodontal patients, healthy subjects and Cebus apella monkeys were evaluated. Forty-five $F$. nucleatum strains from patients, 38 from healthy subjects and seven from $C$. apella were identified and analyzed. Plasmid extraction was performed in all the isolated strains. These elements were found in $26.7 \%$ strains from patients and one strain from $C$. apella. Strains from healthy subjects did not show any plasmid. Most of strains showed two plasmid bands ranging from 4 to $16 \mathrm{~Kb}$, but digestions with endonucleases showed that they belonged to a single plasmid. The plasmid profile was similar and stable in human and monkey strains. Also, plasmids were classified into three groups according to size. Two strains were positive to $\beta$-lactamase production and no plasmid DNA-hybridization with a $\beta$-lactamase gene probe was observed, suggesting a chromosomal resistance.
\end{abstract}

KEYWORDS: Plasmid; Gene; Fusobacterium nucleatum; Cebus apella.

\section{INTRODUCTION}

Fusobacterium nucleatum is a Gram-negative rod, non-sporeforming, non-motile and a strictly anaerobic organism. This bacterium is indigenous of the human and animal oral cavity, and has been involved in several infectious processes such as sinusitis, osteomyelitis, brain or liver abscesses ${ }^{2,3}$. Also, F. nucleatum is a putative pathogen involved in the development of gingivitis in children and adults and of periodontitis in juveniles and adults ${ }^{5,11}$.

Despite the large knowledge about the pathogenic potential and medical aspects of fusobacteria, their metabolic and genetic aspects are little known ${ }^{6}$. In the last years, the use of tools as cloning, sequencing and PCR have given more information about the genetic aspects of $F$. nucleatum $^{2,5}$.

In other microbial groups, several virulence factors have been observed and these factors can be mediated by extrachromosomal DNA elements carrying genes able to synthesize substances destroying host tissues. These factors play an important role in ecological terms, regulating or limiting many microorganisms in their ecosystems. The presence of plasmids in $F$. nucleatum has already been reported ${ }^{10}$.

In this study, the plasmid profile in oral $F$. nucleatum isolated from periodontal patients, health subjects and Cebus apella monkeys, the plasmid stability and the penicillin-resistance genes association with plasmids were evaluated. Monkeys were used because of anatomic similarities with the human oral cavity.

\section{MATERIALS AND METHODS}

1. Bacterial isolation and identification: Subgingival plaque samples from 30 patients with adult periodontitis (age range 18-40 years) from the Periodontology Clinic of Dentistry School, University of São Paulo (SP, Brazil), without sex or race distinction, with clinic and radiographic evidences of periodontitis, including periodontal pockets $\geq 5 \mathrm{~mm}$ were collected. None of them received antibiotics for at least six-month prior to the sample collection. Subgingival dental plaques from 30 periodontally healthy dental students (age range 19-35 years), without sex or race distinction, and without evidences of periodontal disease, were collected. Healthy students did not take antimicrobials six month prior to the sample collection. Also, subgingival plaques from ten Cebus apella monkeys (Experimental Center for Macaco-Prego, UNESP, São Paulo, SP) without evidences of periodontal disease were collected, after injected with Nembutal ${ }^{\circledR 1}$

Samples were dispersed by vortex for 60 seconds and serial dilutions were performed. Aliquots of $0.1 \mathrm{ml}$ of each dilution were transferred onto blood agar and OMATA \& DISRAELY agar ${ }^{13}$, and incubated in atmosphere with $90 \% \mathrm{~N}_{2}+10 \% \mathrm{CO}_{2}$, at $37{ }^{\circ} \mathrm{C}$, for 4 days. 
Bacterial identification was performed according to BENNETT \& DUERDEN $^{3}$, HOLT et al. ${ }^{7}$ and SUMMANEN et al. ${ }^{20}$. Reference strains F. nucleatum ATCC 10953 and F. nucleatum ATCC 25586 were included in all the tests. Identified strains were stored in glycerol $\left(20 \%,-70{ }^{\circ} \mathrm{C}\right)$ and lyophilized.

2. Plasmid profile and stability: Plasmid DNA extraction was performed using a PANTOSTI et al. ${ }^{14}$ method. Briefly, $5 \mathrm{ml}$ of culture in BHI broth supplemented with $0.5 \%$ yeast extract (BHIS, Difco Laboratories) were centrifuged (5,000 x g, 5 minutes) (Jouan, model A-14), and the pellet washed in TES buffer ( $50 \mathrm{mM}$ Tris, $50 \mathrm{mM} \mathrm{Na} \mathrm{Cl}$, $5 \mathrm{mM}$ EDTA), resuspended in $100 \mu \mathrm{g}$ of solution I ( $25 \mathrm{mM}$ Tris, $50 \mathrm{mM}$ glucose, $10 \mathrm{mM}$ EDTA, pH 8.0) with $2 \mathrm{mg} / \mathrm{ml}$ of lysozyme (Amresco) and incubated at $37{ }^{\circ} \mathrm{C}$, for 15 minutes. $200 \mu$ of solution II $(0.2 \mathrm{~N}$ $\mathrm{NaOH}, 1 \%$ SDS) were added to tubes, and incubated on ice for $5 \mathrm{~min}$. Then, $150 \mu \mathrm{l}$ of solution III (3M sodium acetate, $\mathrm{pH} 4.8$ ) were added and incubated on ice for $15 \mathrm{~min}$. After centrifugation $(10,000 \mathrm{x} \mathrm{g}$, 15 minutes, Eppendorf, model 5402), the supernatant was treated with equal volumes of phenol: chloroform (1:1). Aqueous phase was precipitated with 2 volumes of cold ethanol and stored at $-20{ }^{\circ} \mathrm{C}$, for 30 minutes. After centrifugation (10,000 x g, 15 minutes), the pellet was dried and resuspended in $40 \mu \mathrm{l}$ of TE buffer $(10 \mathrm{mM}$ sodium acetate, $1 \mathrm{mM}$ EDTA, pH 8.0) with $20 \mu \mathrm{g} / \mathrm{ml}$ of RNase (10 mg/ml) and incubated at room temperature for $30 \mathrm{~min}$. Obtained DNA was stored at $-20{ }^{\circ} \mathrm{C}$. Also, $10 \mu$ of DNA were run in a $0.7 \%$ agarose gel (type II, Sigma) by electrophoresis in $0.5 \mathrm{X}$ TBE buffer (1 M Tris, 0.9 M Boric acid, 0.01 M EDTA, pH 8.4). DNA extraction for each strain was three times repeated. Plasmid molecular weights were estimated by comparison with the standard weight Supercoiled DNA Ladder (Gibco BRL).

For evaluation of the plasmid stability, plasmid-positive strains were submitted to 50 successive cultures in BHIS, with intervals of 48-72 h. Plasmid extraction was performed every 10 subcultures as described above $^{14}$.

3. $\beta$-lactamase production: The $\beta$-lactamase production by penicillin-resistant strains was evaluated. Briefly, strains were grown in $5 \mathrm{ml}$ of BHIS, and after $20 \mu \mathrm{l}$ were inoculated, in duplicate, onto BHIS agar with penicillin $\mathrm{G}$ (Wyeth Laboratories) in concentrations ranging from 1 to $64 \mu \mathrm{g} / \mathrm{ml}$. Inoculated plates were incubated in anaerobiosis, at $37^{\circ} \mathrm{C}$, for $72 \mathrm{~h}$. Bacterial growth were treated with chloroform vapors for 20 minutes, then plates were opened for 20 minutes until chloroform evaporation. After, $5.0 \mathrm{ml}$ of semi-solid BHIS (0.7\% agar) inoculated with $0.1 \mathrm{ml}$ of $F$. nucleatum ATCC 10953 (susceptible to penicillin G) were pour-plated. Plates were incubated in anaerobiosis, at $37{ }^{\circ} \mathrm{C}$, for $48 \mathrm{~h}$. $\beta$-lactamase production was observed by a growth halo around of the producer strain.

4. Plasmid DNA restriction and Southern blot: Plasmid DNA was extracted by using two based BIRNBOIM \& DOLY ${ }^{4}$ protocols with modifications, where several precipitations with sodium acetate and cold ethanol, and additional treatments with phenol and phenol-chloroform were performed. All the isolated strains were grown into $200 \mathrm{ml}$ of BHIS. A Wizard Plus Maxipreps DNA Purification System (Promega) was also used in accordance to the manufacturer indications. Lyses method by boiling and plasmid purification by cesium-chlorate-ethidium bromide (CsCl-EtBr) gradient were also used according to SAMBROOK et al. ${ }^{18}$. All DNA samples were purified by using a Sequenase Sequencing System protocol (DNA was dissolved in $0.4 \mathrm{ml}$ of ultra pure Milli-Q water, $0.1 \mathrm{ml}$ of $4 \mathrm{M} \mathrm{NaCl}$ and $0.5 \mathrm{ml}$ of $13 \% \mathrm{PEG}_{8000}$. After homogenization, tubes were incubated at $4{ }^{\circ} \mathrm{C}$, for 30 minutes, and centrifuged at 10,000 $\mathrm{x} \mathrm{g}$, for 15 minutes. DNA was dried at room temperature and resuspended in TE buffer).

$0.1 \mu \mathrm{g}$ to $0.5 \mu \mathrm{g}$ of DNA samples were restricted overnight with endonucleases: BamH I, Bgl II, EcoR I, Hinc II, Hind III, Pst I and Sal I (New England Biolabs) according to manufacturer. Plasmid molecular fragments weights were determined by using a lambda DNA-Hind III digested as a standard weight (New England Biolabs) and an Eagle-Eye program.

4.1. Probe to $\beta$-lactamase: $\beta$-lactamase gene probe from pUC18 plasmid ampicillin-resistance gene was obtained ${ }^{18}$. Plasmid pUC18 was restricted with $S c a$ I and $B s a$ I, producing a $2.3 \mathrm{~Kb}$ and $0.4 \mathrm{~Kb}$ bands. The $0.4 \mathrm{~Kb}$ band was eluted and purified by using a PrepA Gene ${ }^{\circledR}$ System protocol (Life Science Research Products Bio-Rad), and a DIG-DNA Labeling and Detection Kit (Boehringer Mannheim) was used as probe marker.

4.2. Southern blot: Plasmid samples from penicillin-resistant $F$. nucleatum were obtained. Also, a DNA from Saccharomyces cerevisiae strain IH \# 1784 (Herskowitz, I., Univ. California, San Francisco, USA) as a negative control, a plasmid pUC18 as a positive control, and a standard $1 \mathrm{~Kb}$ DNA Ladder (Gibco BRL) were used.

The membrane transference using a nylon membrane (Zeta-Probe Blotting Membrane - Life Science Research Products Bio-Rad) in a vacuum blotting system (Pharmacia, LKB, Biotechnology) was performed. A denature solution (1.5 M NaCl, $0.5 \mathrm{M} \mathrm{NaOH})$ was added for 20 minutes and then, a neutralizing solution $(1.5 \mathrm{M} \mathrm{NaCl}, 0.5 \mathrm{M}$ Tris-HCl, $\mathrm{pH} 7.2,1.0 \mathrm{mM}$ EDTA, $\mathrm{pH}$ 8.0) was used for $20 \mathrm{~min}$. Transference was performed changing the neutralizing solution for a transference solution (20 X SSC, $3 \mathrm{M} \mathrm{NaCl}, 0.3 \mathrm{M}$ Tri-sodium citrate, $\mathrm{pH}$ 7.0), for $1 \mathrm{~h}$. Membrane was washed in $10 \mathrm{X}$ SSC solution and dried on filter paper at room temperature, and DNA was fixed with UV light for $3 \mathrm{~min}$.

4.3. Hybridization: Nylon membrane was pre-hybridized with $20 \mathrm{ml}$ of pre-hybridization solution (5X SSC, $0.1 \%$ N-laurosilsarcosine, $0.02 \%$ SDS, $1 \%$ blocking reagent from DIG-DNA labeling and detection kit), at $65{ }^{\circ} \mathrm{C}$, for $3 \mathrm{~h}$ using a hybridization machine (Hybaid Model Maxi 14). This solution was discarded and $20 \mathrm{ml}$ of pre-hybridization solution with $100 \mathrm{ng} / \mu \mathrm{l}$ of a denatured $\beta$-lactamase probe $\left(100{ }^{\circ} \mathrm{C}\right.$, 10 minutes) were added, and hybridization was performed overnight. Membrane was washed twice with a washing solution I (2X SSC, $0.1 \%$ SDS) for $5 \mathrm{~min}$, at room temperature. Washing solution II (0.1X SSC, $0.1 \%$ SDS ) was used twice for additional washing, at $65{ }^{\circ} \mathrm{C}$, for 15 minutes. Membrane was dried and revelation was performed. Another hybridization at low stringent conditions was also performed.

\section{RESULTS}

Bacterial isolation: Forty-five oral $F$. nucleatum from periodontal patients, 38 from health subjects and 7 from $C$. apella monkeys were obtained.

Plasmid profile and stability: Plasmids were observed in 12 out of 
45 strains (26.7\%) from periodontal patients and in 1 out of 7 strains from $C$. apella monkeys. All the strains showed two plasmid bands except strain D82 that showed four bands. Bands were approximately between $4 \mathrm{~Kb}$ and $\geq 16 \mathrm{~Kb}$ (Table 1). Strains harboring plasmids were recovered from different patients, except strains D40 and D41, which belonged to a single patient. No strain from healthy subjects harbored plasmids. Also, the plasmid profile of the monkey strain (M6) was similar to the human strains (D33, D40 and D41). Isolates D6, D33, D40 and D82 from periodontal patients showed plasmids, but these strains were lost during maintenance and were not used for plasmid DNA analysis.

\section{Table 1}

Presence of plasmids in 12 oral F. nucleatum recovered from periodontal patients (D) and one from C. apella monkey (M)

\begin{tabular}{lcr}
\hline \multirow{2}{*}{ Strain } & \multicolumn{2}{c}{ Plasmid bands } \\
\cline { 2 - 3 } & Number & \multicolumn{1}{c}{ Size } \\
\hline D1, D6 & 2 & $6.5 \mathrm{~Kb}$ \\
& & $4.5 \mathrm{~Kb}$ \\
D12, D17, D81, D84, D513, D518 & 2 & $11 \mathrm{~Kb}$ \\
& & $6.5 \mathrm{~Kb}$ \\
D33, D40, D41 & 2 & $16 \mathrm{~Kb}$ \\
& & $12 \mathrm{~Kb}$ \\
D82 & 4 & $16 \mathrm{~Kb}$ \\
& & $10 \mathrm{~Kb}$ \\
& & $7.5 \mathrm{~Kb}$ \\
M6 & & $4.5 \mathrm{~Kb}$ \\
& 2 & $16 \mathrm{~Kb}$ \\
& & $12 \mathrm{~Kb}$ \\
\hline
\end{tabular}

Table 2 shows the plasmid presence during subcultures at different times. Reference strain F. nucleatum ATCC 10953 did not show any plasmids. In the other strains, plasmids appeared at least twice or more times, showing the same molecular weight during subcultures.

$\beta$-lactamase production: Two penicillin-resistant human strains (D1 and D12) produced $\beta$-lactamase enzyme.

Table 2

Presence of plasmids in nine oral $F$. nucleatum during 50 subcultures

\begin{tabular}{ccccccc}
\hline \multirow{2}{*}{ Strain } & \multicolumn{7}{c}{ Presence of plasmid } \\
\cline { 2 - 7 } & $1^{\circ}$ & $10^{\circ}$ & $20^{\circ}$ & $30^{\circ}$ & $40^{\circ}$ & $50^{\circ}$ \\
\hline D1 & + & + & - & - & + & + \\
D12 & + & + & + & + & + & - \\
D17 & + & + & + & + & + & + \\
D41 & + & - & - & - & + & - \\
D81 & + & + & - & + & + & - \\
D84 & + & + & - & - & + & + \\
D513 & + & + & + & + & - & - \\
D518 & + & + & + & - & + & - \\
M6 & + & + & - & + & + & - \\
ATCC 10953* & - & - & - & - & - & - \\
\hline
\end{tabular}

+: Presence of plasmid; -: No plasmid; D: Periodontal patient strain; M: $C$. apella monkey strain; * Reference strain F. nucleatum ATCC 10953
Plasmid DNA restriction: Plasmid-positive strains (D1, D3, D12, D17, D41, D81, D84, D513, D518 and M6) were submitted for a maxipreps DNA extraction. Sometimes, a small DNA amount or no DNA or degraded DNA was observed. No DNA sample was obtained with $\mathrm{CsCl}$ gradient method.

DNA from strains D1, D12, and D81 were restricted with EcoR I, and from D17 and D513 with Hinc II. EcoR I partially digested DNA from strains D1, producing a $4.2 \mathrm{~Kb}$ band (Fig. 2), and D12 or D81, producing a $5.8 \mathrm{~Kb}$ and $0.8 \mathrm{~Kb}$ bands (Fig. 1). Hinc II restricted DNA from strain D17 producing a $3.1 \mathrm{~Kb}, 2.3 \mathrm{~Kb}$ and $1.1 \mathrm{~Kb}$ bands (Fig. 2), and from D513, only a $6.0 \mathrm{~Kb}$ band. Endonucleases BamH I, Bgl II, Hind III, Pst I and Sal I did not digest any DNA sample.

Hybridization: Plasmid DNA from penicillin-resistant (D1 and D12) or susceptible (D81 and D17) F. nucleatum did not hybridize with $\beta$ lactamase probe. Similar results were observed when hybridization was performed at low stringent conditions.

\section{DISCUSSION}

Extrachromosomal elements such as plasmids have been observed in several bacterial species. These genetic elements may change the bacterial physiologic properties increasing its pathogenic potential, affecting the taxonomic position and spreading its properties to other bacterial species.

The presence of plasmids observed in oral $F$. nucleatum strains isolated from periodontal patients and its absence in healthy subjects

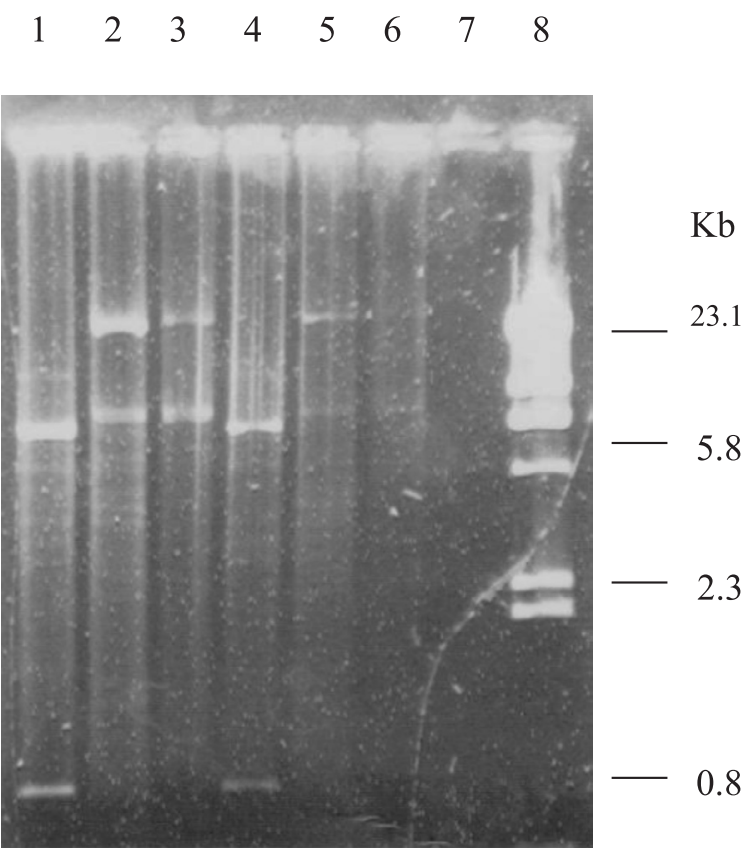

Fig. 1 - Agarose gel electrophoresis of plasmid DNA from F. nucleatum. Lane 1, strain D12 digested with EcoR I; lane 2, strain D12 digested with Hind III; lane 3, strain D12 without endonuclease (Control); lane 4, strain D81 digested with EcoR I; lane 5, strain D81 digested with Hind III; lane 6, strain D81 without endonuclease (Control); lane 7, no DNA; lane 8, Lambda DNA-Hind III digest. 


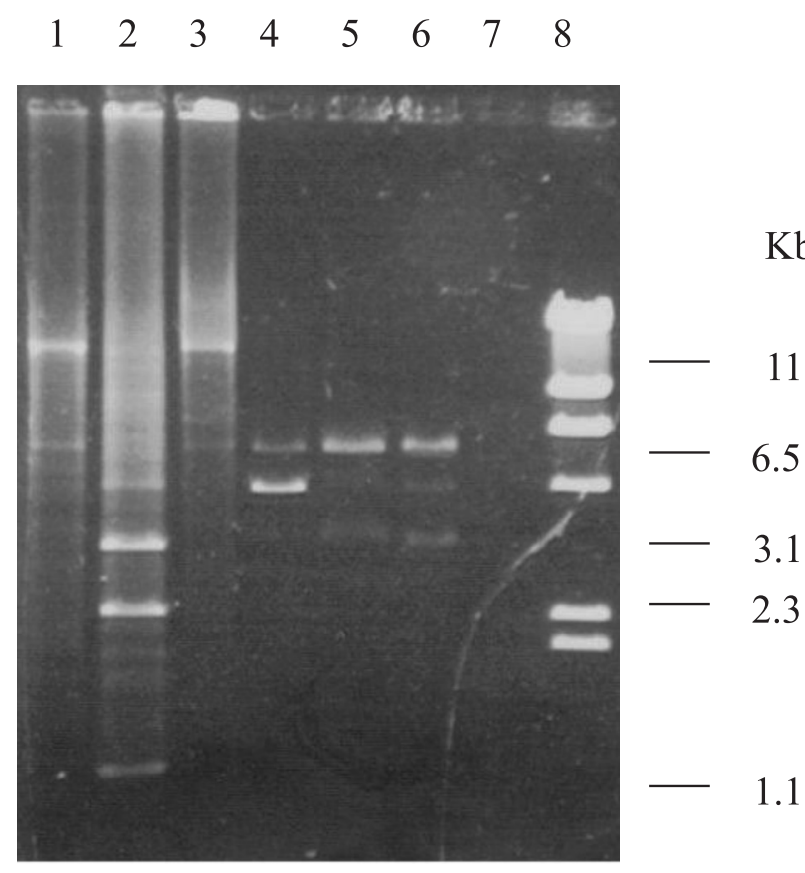

Fig. 2 - Agarose gel electrophoresis of plasmid DNA from F. nucleatum. Lane 1, strain D17 digested with EcoR I; lane 2, strain D17 digested with Hinc II; lane 3, strain D17 without endonuclease (Control); lane 4, strain D1 digested with EcoR I; lane 5, strain D1 digested with Hinc II; lane 6, strain D1 without endonuclease (Control); lane 7, no DNA; lane 8, Lambda DNA-Hind III digest.

suggest an association with some pathogenic factors. McKAY et al. ${ }^{10}$ reported the presence of plasmids (ranged from 6.0 to $6.6 \mathrm{~Kb}$ ) in $18 \%$ of the tested $F$. nucleatum isolated from periodontal patients and healthy subjects, without distinction among both studied groups, and these elements were considered cryptic. This is the only report of plasmids in this group.

Plasmids were observed in $26.7 \%$ of the $F$. nucleatum recovered from periodontal patients and in one (14\%) out of seven strains recovered from $C$. apella monkeys. However, no $F$. nucleatum recovered from healthy subjects harbored plasmids. Plasmid profile in the animal strain was similar to the human strains, suggesting a possible microbial crosstransmission by water or food (among animals and keep-staff). On the other hand, studies using a larger number of monkey and keep-staff strains would be necessary to obtain any definitive conclusion.

Most of tested F. nucleatum was susceptible to penicillin G. However, strains D1 and D12 were resistant to penicillin $(256 \mu \mathrm{g} / \mathrm{ml})$, maybe due to a $\beta$-lactamase production. Studies have reported a $\beta$-lactamase production in $F$. nucleatum, but no gene has been identified ${ }^{8,12,22,23,24}$. Also, that high resistance observed in both strains (D1 and D12) suggests the presence of any penicillin-resistance marker such as a plasmid or a chromosomal gene. Bacterial plasmids codifying for antimicrobial resistance have been frequently observed ${ }^{16,17,19,21}$.

The $\beta$-lactamase production for strains D1 and D2 by chromosomal or plasmid genes was detected by using a hybridization assay with a $\beta$ lactamase gene probe, and no hybridization was observed suggesting that $\beta$-lactamase production was chromosomally mediated or the used probe from pUC18 did not show any homology with genes belonging to Fusobacterium spp. Most of sequenced $\beta$-lactamases genes from different bacterial groups, such as Salmonella, Klebsiella, Mycobacterium, Lysobacter, Nocardia and Streptomyces, showed some homology (> $55 \%$ ) with Escherichia coli genes (GenBank data). On the other hand, LIVERMORE $^{9}$ showed differences among $\beta$-lactamases mediated for plasmid and chromosome. In Bacteroides fragilis, plasmid genes producing $\beta$-lactamases may be different from those observed in enterobacteria or other aerobic Gram-negative bacteria ${ }^{16}$.

Presence of plasmid was stable during bacterial subcultures, but these elements were present or absent in some DNA extractions, suggesting that technical problems can be a trouble in plasmid isolation and observation. The Mini-prep and Maxi-prep plasmid DNA extraction protocols were used, but the DNA amounts obtained in Mini-prep where small and enough only to visualize Max-prep protocols didn't get enough DNA in all strains for endonucleases digestion. Also, sometimes the DNA was degrated. This DNA degradation might be due to DNase enzymes produced by $F$. nucleatum ${ }^{15}$. McKAY et al. ${ }^{10}$ also reported that small DNA amounts are commonly recovered from this microbial group.

In this study, only EcoR I and Hinc II were able to restrict plasmid DNA from the tested $F$. nucleatum. The same endonucleases restricted the plasmids isolated by McKAY et al. ${ }^{10}$. Also, endonucleases BamH I, Bgl II, Hind III, Pst I and Sal I, did not digest any isolated plasmid. In addition, BamH I, Pst I and $\mathrm{Sal}$ I recognize sites rich in $\mathrm{G}$ and also did not restricted McKAY et al. isolated plasmids. It is well known that $F$. nucleatum has a low $\mathrm{G}+\mathrm{C}$ content $(27 \%-28 \%)$, and it might explain why these enzymes were not able to restrict plasmid from $F$. nucleatum.

Plasmid DNA from strains D12 and D81 were restricted with EcoR I and produced two 5.8 and $0.8 \mathrm{~Kb}$ bands, suggesting a true molecular weight of approximately $6.6 \mathrm{~Kb}$. Also, the two observed bands in the intact plasmid with sizes between 10 and $12 \mathrm{~Kb}$, and between 6 and 7 $\mathrm{Kb}$, belong to a single plasmid, but in two different forms. Plasmid from strain D17 was restricted with Hinc II and three bands with approximately 3.1, 2.3 and $1.1 \mathrm{~Kb}$ were observed, suggesting a molecular weight of $6.5 \mathrm{~Kb}$. Plasmid DNA from strain D513 was restricted with Hinc II in a unique site, producing an approximately $6.0 \mathrm{~Kb}$ band. Our data show that strains D12, D81, D17 and D513 harbored plasmids with similar size (Table 1). Plasmid from strains D12 and D81 showed two common sites for Eco RI, while plasmids from strains D17 and D513 showed a different restriction profile. Also, a partial DNA digestion from strain D1 was obtained with EcoR I, producing a $4.2 \mathrm{~Kb}$ band (whole plasmid size).

After restriction analysis, plasmids were grouped according to their molecular weight: group I, approximately $4.2 \mathrm{~Kb}$; group II, between 6.0 and $6.6 \mathrm{~Kb}$; and group III, between 12 and $16 \mathrm{~Kb}$. Plasmids from group III were not digested due to the small DNA amount obtained. In addition, plasmids belonging to the second group were also reported by McKAY et al. ${ }^{10}$, but no function was observed.

Certainly, these results indicate the need of a better plasmid characterization of the F. nucleatum species identifying their genetic content and determining in ecologic and pathogenic terms the role that these elements, still considered cryptic, could play in human periodontal processes. 


\section{RESUMO}

\section{Perfil plasmidial de Fusobacterium nucleatum isolados da cavidade bucal de humanos e primatas Cebus apella}

Fusobacterium nucleatum é um anaeróbio estrito e considerado membro da microbiota indígena da cavidade bucal humana. É comumente observado em diferentes infecções monomicrobianas e mistas em humanos e animais. O objetivo deste estudo foi avaliar o perfil plasmidial de $F$. nucleatum orais isolados de pacientes com doença periodontal, indivíduos sadios, e de macacos Cebus apella, e verificar a estabilidade plasmidial e a associação com genes de resistência à penicilina. Quarenta e cinco cepas de $F$. nucleatum orais isoladas de pacientes, 38 de indivíduos sadios e sete de macacos C. apella, foram examinadas. A extração plasmidial realizada detectou plasmídios em $26,7 \%$ das cepas humanas e em apenas uma cepa de $C$. apella. A maioria das cepas apresentou duas bandas plasmidiais variando de 4 a $16 \mathrm{~Kb}$, e as digestões com endonucleases demonstraram serem essas bandas pertencentes a um único plasmídio, sendo classificados em três grupos segundo o tamanho. Cepas de indivíduos sadios não abrigaram plasmídios. O perfil plasmidial foi similar e estável nas cepas isoladas de humanos e de macacos. Duas cepas foram $\beta$-lactamase-positivas, e não se observou hibridização de DNA plasmidial com a sonda do gene da $\beta$-lactamase, sugerindo-se que a resistência à penicilina nestas cepas é cromossômica.

\section{ACKNOWLEDGMENTS}

The authors thank Ana Cláudia Okamoto for her technical assistance. This study was partially supported by Fundação de Amparo à Pesquisa do Estado de São Paulo (FAPESP), Grant No. 96/02475-9.

\section{REFERENCES}

1. AVILA-CAMPOS, M.J.; RAYMUNDO, N.L.S.; FARIAS, L.M. et al. - Isolation and identification of strains of Bacteroides fragilis group from digestive tract of Callithrix penicillata marmosets. Lab. anim., 24: 68-70, 1990.

2. AVILA-CAMPOS, M.J.; SACCHI, A.T.; WHITNEY, A.M.; STEIGERWALT, A.G. \& MAYER, L.W. - Arbitrarily primed-polymerase chain reaction for identification and epidemiologic subtyping of oral isolates of Fusobacterium nucleatum. J. Periodont., 70: $1202-1208,1999$

3. BENNETT, K.W. \& DUERDEN, B.I. - Identification of fusobacteria in a routine diagnostic laboratory. J. appl. Bact., 59: 171-181, 1985.

4. BIRNBOIM, H.C. \& DOLY, J. - A rapid alkaline extraction procedure for screening recombinant plasmid DNA. Nucleic Acids Res., 7: 1513-1523, 1979.

5. BOLSTAD, A.I.; JENSEN, H.B. \& BAKKEN, V. - Taxonomy, biology, and periodontal aspects of Fusobacterium nucleatum. Clin. Microbiol. Rev., 9: 55-71, 1996.

6. BOUMA, C.L.; REIZER, J.; REIZER, A.; ROBRISH, S. A. \& THOMPSON, J. - 6phospho- $\alpha$-D-glucosidase from Fusobacterium mortiferum: cloning, expression, and assignment to family 4 of the glycosylhydrolases. J. Bact., 179: 4129-4137, 1997.
7. HOLT, J.G.; KRIEG, N.R.; SNEATH, P.H.A.; TALEY, J.T. \& WILLIAMS, S.T. - Genus Fusobacterium. In: Bergey's manual of determinative Bacteriology. 9. ed. Baltimore, Williams \& Wilkins, 1994.

8. JACOBS, M.R.; SPANGLER, S.K. \& APPLEBAUN, P.C. - Beta-lactamase production and susceptibility of US and European anaerobic gram-negative bacilli to beta-lactams and other agents. Europ. J. clin. Microbiol. infect. Dis., 11: 1081-1093, 1992.

9. LIVERMORE, D.M. - $\beta$-lactamases in laboratory and clinical resistance. Clin. Microbiol. Rev., 8: 557-584, 1995.

10. McKAY, T.L.; KO, J.; BILALIS, Y. \& DiRIENZO, J.M. - Mobile genetic elements of Fusobacterium nucleatum. Plasmid, 33: 15-25, 1995.

11. MOORE, W.E.C.; RANNEY, R.R. \& HOLDEMAN, L.V. - Subgengival microflora in periodontal disease: cultural studies. In: GENCO, R.J. \& MERGENHAGEN, S.E., ed. Host-parasite interactions in periodontal disease. Washington, American Society of Microbiology, 1982. p. 13-26.

12. NORD, C.E. \& HEDBERG, M. - Resistance to $\beta$-lactam antibiotics in anaerobic bacteria. Rev. infect. Dis. , 12 (suppl. 2): S231-S234, 1990.

13. OMATA, R.R. \& DISRAELY, M.N. - A selective medium for oral fusobacteria. J. Bact. 72: 677-680, 1956.

14. PANTOSTI, A.; CERQUETTI, M.; COLANGELI, R. \& D’AMBROSIO, F. - Detection of intestinal and extra-intestinal strains of enterotoxigenic Bacteroides fragilis by the HT-29 cytotoxicity assay. J. med. Microbiol., 41: 191-196, 1994.

15. PORSCHEN, R.K. \& SONNTAG, S. - Extracellular deoxyribonuclease production in anaerobic bacteria. Appl. Microbiol., 27: 1031-1033, 1974.

16. RASMUSSEN, B.A; BUSH, K. \& TALLY, F.P. - Antimicrobial resistance in Bacteroides. Clin. infect. Dis., 16 (suppl. 4): S390-S400, 1993.

17. SAIER Jr., M.H.; PAULSEN, I.T. \& MATIN, A. - A bacterial model system for understanding multi-drug resistance. Microbiol. Drug Resist., 3: 289-295, 1997.

18. SAMBROOK, J.; FRITSCH, E.F. \& MANIATS, T. - Molecular cloning: a laboratory manual. 2. ed. New York, Cold Spring Harbor Laboratory Press, 1989.

19. SEBALD, M. - Genetic basis for antibiotic resistance in anaerobes. Clin. infect. Dis., 18: 297-304, 1994.

20. SUMMANEN, P.H.; BARON, E.J.; CITRON, D.M. et al. - Wadsworth anaerobic Bacteriology manual. 5. ed. Singapore, Star Publ., 1993.

21. TALLY, F.P.; CUCHURAL Jr., G.J. \& MALAMY, M.H. - Mechanisms of resistance and resistance transfer in anaerobic bacteria: factors influencing antimicrobial therapy. Rev. infect. Dis., 6 (suppl. 1): S260-S269, 1984.

22. TUNÉR, K.; LINDQVIST, L. \& NORD, C.E. - Purification and properties of a novel $\beta$ lactamase from Fusobacterium nucleatum. Antimicrob. Agents Chemother., 27: 943-947, 1985.

23. TUNÉR, K. \& NORD, C.E. - Antibiotic susceptibility of anaerobic bacteria in Europe. Clin. infect. Dis., 16 (suppl. 4): S387-S389, 1993.

24. VAN WINKELHOFF, A.J.; WINKEL, E.G.; BARENDREGT, D. et al. - $\beta$-lactamase producing bacteria in adult periodontitis. J. clin. Periodont., 24: 538-543, 1997

Received: 26 August 2002

Accepted: 18 December 2002 